\title{
Tourism as a leverage of internationalization for consumer goods firms: A case study approach
}

DOI:

10.1108/S1474-7979(2009)0000020006

Link to publication record in Manchester Research Explorer

\section{Citation for published version (APA):}

Poulis, K., \& Yamin, M. (2009). Tourism as a leverage of internationalization for consumer goods firms: A case study approach. In Advances in International Marketing/Adv. Int. Mark. (Vol. 20, pp. 69-85). (Advances in International Marketing). JAI Press Ltd. https://doi.org/10.1108/S1474-7979(2009)0000020006

\section{Published in:}

Advances in International Marketing|Adv. Int. Mark.

\section{Citing this paper}

Please note that where the full-text provided on Manchester Research Explorer is the Author Accepted Manuscript or Proof version this may differ from the final Published version. If citing, it is advised that you check and use the publisher's definitive version.

\section{General rights}

Copyright and moral rights for the publications made accessible in the Research Explorer are retained by the authors and/or other copyright owners and it is a condition of accessing publications that users recognise and abide by the legal requirements associated with these rights.

\section{Takedown policy}

If you believe that this document breaches copyright please refer to the University of Manchester's Takedown Procedures [http://man.ac.uk/04Y6Bo] or contact uml.scholarlycommunications@manchester.ac.uk providing relevant details, so we can investigate your claim.

\section{OPEN ACCESS}




\section{TOURISM AS A LEVERAGE OF INTERNATIONALIZATION FOR CONSUMER GOODS FIRMS: A CASE STUDY APPROACH}

\section{Konstantinos Poulis and Mo Yamin}

\section{INTRODUCTION}

Large-scale incoming tourism potentially creates a multinational market within the domestic economy of the recipient countries. More specifically, in a number of countries, there is a large influx of 'foreign' consumers, or tourists, from many countries and for a significant part of the year. As can be seen from Table 1, for countries such as France, Spain, Austria, or Greece the annual influx of tourists exceeds the population of these countries by very large margins.

For such countries, tourism transforms a nationally homogeneous consumer market into a multinational or multicultural consumer market during the tourist season, which can be most of the year. This is likely to be particularly significant for FMCG firms in the tourist-receiving countries. For example, tourists consume beers, soft drinks, shampoos, and ice creams while on holiday and thus, the size of the market for FMCGs will expand significantly over the tourist season. Additionally, it is likely that in their consumption decisions, tourists from particular countries reflect traits of their

\footnotetext{
New Challenges to International Marketing Advances in International Marketing, Volume 20, 69-85 Copyright (C) 2009 by Emerald Group Publishing Limited All rights of reproduction in any form reserved ISSN: 1474-7979/doi:10.1108/S1474-7979(2009)0000020006
} 
Table 1. Incoming Tourism and Domestic Population.

\begin{tabular}{lccc}
\hline & $\begin{array}{c}\text { Tourists Arrivals } \\
\text { (Millions of Tourists) }\end{array}$ & $\begin{array}{c}\text { Population of Country } \\
\text { (Millions of People) }\end{array}$ & $\begin{array}{c}\text { \% of Tourists to the } \\
\text { Domestic Population }\end{array}$ \\
\hline France & 77 & 60 & 128 \\
Spain & 50 & 40 & 125 \\
Italy & 40 & 57 & 70 \\
Austria & 18 & 8 & 225 \\
Greece & 13 & 11 & 118 \\
\hline
\end{tabular}

Source: World Tourism Organization.

nationality and hence be somewhat distinct from not only the 'native' populations but also from each other. Consequently, companies not only face a much larger market but one that is also likely to be highly heterogeneous in terms of consumer tastes and preferences; FMCG firms essentially operate in a multinational consumer market during the tourist season.

This study seeks to explore the implications of this fact for the internationalization of firms domiciled in the tourist-receiving countries. ${ }^{1}$ The aim of this chapter is to contribute to the internationalization literature by considering the possible influence of inward tourism in stimulating the internationalization of SMEs headquartered in the tourist-receiving countries. The insights of this chapter rely on the existing literature and findings from case studies of internationalizing SMEs in the FMCG sectors in Greece. The structure of the chapter is as follows. Section 2 considers the implications of tourism for internationalization in the context of the existing literature on internationalization, particularly the literature on the relevance of knowledge. In this section, we attempt to show how in responding to the presence of tourist as a significant component of their domestic markets, SMEs effectively gain information/knowledge that is also 'international' in character. For example, they may be able to gain brands with significant international appeal or equity even before they operate in foreign countries (or even advertise) there. Section 3 explains the case selection methodology and reports findings on the link between internationalization and inbound tourism revealed by the experience of firms included in the study. Section 4 develops five propositions, based on the extant literature and our case study findings, relating to the impact of incoming tourism on the internationalization of SME in the tourist recipient countries. The propositions emphasize knowledge development; the leveraging of local, 'ethnobrands' and the key role played by the Internet to maintain communication with tourist customers and the role that this plays in firms' internationalization. 
Section 5 concludes the chapter indicating the limitations of the present study and drawing out implications for future research.

\section{KNOWLEDGE AND INTERNATIONALIZATION}

Lack of knowledge about foreign markets is recognized as a key impediment to firms' internationalization. This is because the accumulation of necessary knowledge is very time-consuming, country-specific with significant differences of needed information across markets and depends on the degree of the firm's internationalization (Johanson \& Vahlne, 1977, 1990; Luostarinen, 1979; Denis \& Depelteau, 1985; Johanson \& Wiedersheim-Paul, 1975; Eriksson \& Chetty, 2003). Research, focusing specifically on export barriers also highlights the importance of knowledge. Leonidou (2004), by pulling together results from 32 empirical studies, ranked a number of barriers in terms of the overall impact. Lack of knowledge is invariably ranked as the factor with the highest negative impact on SME internationalization.

However, once achieved, market knowledge can provide a platform for further internationalization of the firm. Researchers highlight both internal and external knowledge accumulation and how these lead to international growth of the firm by internalizing information. An increasing number of studies dealing with the issue of knowledge creation in the internationalization literature suggest, therefore, that the knowledge variable is of critical importance for MNEs (Kogut \& Zander, 1993; Yang, Leone, \& Alden, 1992; Liesch \& Knight, 1999). As a result, knowledge gained through market screening and involvement is an essential driver of internationalization, which can define its degree and pace (Hadley \& Wilson, 2003). Slow rates of generating this experiential knowledge can lead to reduced internationalization pace and vice versa (Johanson \& Vahlne, 1977), while empirical results show that knowledge as a result of being exposed to a variety of market knowledge sources, creates more opportunities than relying solely on internal capabilities (Inkpen, 1996; Osland \& Yaprak, 1995).

\subsection{Incoming Tourism: Reduction in the Knowledge Barrier to Internationalization}

Given the importance of market knowledge for export development and internationalization, it is somewhat surprising that the relevance of incoming tourism for firm internationalization has not been seriously 
considered in prior research. Extant research on the barriers to exports and internationalization specifically indicates that lack of contact with foreign consumers is a major barrier to export initiation and development. The study by Leonidou (2004), classifies this as a 'very high impact' export barrier; more specifically he pointed out that

\footnotetext{
Identifying customers in overseas markets constitutes a serious impediment for many would be and current exporters. This can be attributed to three major factors (1) large geographic distances separating sellers and buyers in foreign markets, hampering communication between them; (2) the characteristically half hearted approach taken by many firms towards carrying out market research in overseas markets and (3) the limited exposure to sources listing potential customers.
}

Clearly firms in tourist-receiving countries have an unusual opportunity to become acquainted with (some) foreign consumer behaviors, attitudes, and needs without actually having to move beyond their borders or having to invest as much in international market research and screening as would otherwise be necessary. Firms in tourist-receiving countries can assess the attractiveness of their offerings/brands among foreign consumers; they can gain knowledge of what kind of product categories are usually purchased by which ethnic or demographic groups helping define the product portfolio by which they may enter a specific foreign market; similarly, they may gain knowledge that enables them to specify standardized or adapted promotional campaigns and product attributes. Additionally, research findings that a firm's exposure to culturally diverse markets can facilitate its ability to conduct international operations (Hadley \& Wilson, 2003; Eriksson \& Chetty, 2003; Ghoshal, 1987) suggest that firms operating in a tourismreceiving country can capitalize on this influx of an additional consumer base which is multicultural in character.

In general, a key feature of macro-environment in countries with largescale inbound tourism is the opportunity to create firm-specific knowledge, relating specifically to consumer behavior that is simultaneously both domestic and international. This is a valuable potential advantage compared with the environments in which tourism is not an important feature; in the latter context the relevance of domestic knowledge for international expansion is usually highly uncertain and risky (Johanson \& Vahlne, 1977).

\subsection{Tourism and the Brand Enhancement}

SMEs, especially those in small economies such as Greece, usually carry a strong country-of-origin image on their shoulders unlike their global 
counterparts, which often have a seamless entity that is not anchored on specific countries. This national rather than global image is often perceived as an inherent drawback of local firms in their effort to internationalize their operations. While there is an assertion in the literature that all firms strive to develop a global image for their brands (Yu, 2003; Craig \& Douglas, 2000), inadequate financial resources usually impedes SMEs to further enhance their brand equity among foreign consumers who could otherwise provide a platform of demand for international expansion.

However, the branding disadvantage of SMEs may only be valid for a firm selling in a foreign country to consumers within their country of residence. In this case, there are inherent problems for foreign SMEs associated primarily with the lack of brand awareness, financial scarcity, and the lack of access to distribution channels. However, in cases when the international consumers are within the country of operation of the firm - where it has an established access to distribution channels, i.e. in the case of foreign (tourists) consumers in the home country of the SME - the 'locality' of the brand may not be as great a disadvantage and may even become an advantage.

There is an opportunity for firms to address to an increasing number of foreign consumers domestically in a way that would otherwise cost enormous amounts of money, i.e. launch an international promotional campaign to develop brand awareness and enhance international brand equity. After all, a main premise behind the alleged brand superiority of global brands is the familiarity concept (Cheng, Blankson, Wu, \& Chen, 2005). Consumers are familiar with the properties of a brand and this leads to favorable purchasing. We do not know yet though whether the familiarity concept is equally applicable for a foreigner consuming products in a country beyond his/her usual habitat. Familiarity may be replaced by other constructs and attitudes, such as experimentation, curiosity, culturally oriented exploration, or simply a deliberate get-away from the normal daily routines back home. After all, the essence of being a tourist according to one of the most cited sociologists of tourism, MacCannell (1976) is to find reality 'out there' through authentic experiences. If this is the case indeed and this unitary type of tourist exists, local firms not only have an edge for local consumption over their multinational rivals who enjoy an established brand reputation but also this consumption can lead to satisfaction, repurchasing, and even loyalty when the tourist gets back home.

Therefore, the opportunity for the firm lies in the fact that there is low cost way (compared to the 'usual' internationalization process) to develop and enhance the international brand equity and consequently, create and retain a significant number of customers abroad. 


\section{METHODOLOGY AND INTERVIEW ANALYSIS}

Seven Greek firms with an already existing exporting activity were approached to serve as case studies. Following Patton (1990), sampling was based on a maximum variation logic trying to include firms from a diversified range of industries such as food, beverage, and cosmetics since the nature of the industry is an ubiquitous factor in the international business literature (Theodosiou \& Leonidou, 2003).

Four of these firms have never really thought of tourism as a leverage to internationalize their activities. They exploit tourism as a sales opportunity domestically but they have not specifically targeted incoming tourists as qualitatively distinct segments. In particular, respondents in these four companies were quite explicit that they were not particularly interested or focused on tourist segments of their respective markets. In effect, these firms treated sales to tourists as an additional bonus to their main business. Although these firms had significant export activity, such activity was overwhelmingly in the Balkans and they have minimal or no export activities in countries where the majority of tourists to Greece emanate (e.g. Western Europe and, increasingly, Asian countries). These firms' export activity exactly mirrors the dominant pattern of exporting in Greece.

The remaining three are firms who have realized the importance of tourism and they do implement programs towards a better exploitation of tourism as a platform of internationalization. One firm is active in the beverages sector and two firms in the cosmetics sector. All are SMEs based in Greece, an archetypal tourism destination for international tourists. Greece was chosen as the field of study due to the fact that it is a mature tourism destination with a relatively stable tourism clientele every year, it has a huge tourism population compared with the domestic market, has a large number of SMEs striving for internationalization, and is the home country of one of the authors, something which assisted towards the implementation of a deliberate, maximum variation sampling logic.

Semi-structured interviews took place with key people in the firms resulting to seven interviews. An official request was made indicating that we would like the firm to decide who is the ideal person to answer our question with respect to the research problem under scrutiny. Due to the fact that all three cases are SMEs, only a few number of people deal with this issue. Table 2 describes the key characteristics of the three sampled firms. 
Table 2. Cases Descriptive Information.

\begin{tabular}{lll}
\hline & \multicolumn{2}{c}{ The Cases } \\
\hline Case $\mathrm{X}$ & \multicolumn{1}{c}{ Case $\mathrm{Y}$} & \multicolumn{1}{c}{ Case $\mathrm{Z}$} \\
\hline Industry: cosmetics & Industry: beverages & Industry: cosmetics \\
International activity: & International activity: & International activity: \\
13 countries & 30 countries & 21 countries \\
Interviews: 2 & Interviews: 3 & Interviews: 2 \\
Respondents: Human & Respondents: Trade and & Respondents: Marketing \\
Resources and Export & Marketing, Area Sales & Manager, Group Product \\
Marketing Managers & and Senior Brand & Manager \\
& Manager & \\
\hline
\end{tabular}

\subsection{Inbound Tourism and Firm Internationalizations: Interview Analyses}

In this section, based on responses of the managers interviewed, we consider the role tourism plays for the international activity of the firms; additionally, we highlight the active reliance on the Internet by these firms in order to maintain communication and build relationship with their tourist customers.

\subsubsection{Tourism and Export Development}

The key benefit of tourism presence in the mother country of the cases is the knowledge factor. This knowledge covers several issues ranging from preferable brand strategies to consumers' needs and behaviors. As an executive from firm $X$ stressed:

... for all these (strategic decisions of international scope) tourism was the source.

The source of information ...

Tourists are a convenient way to get feedback on foreign consumers' needs and behaviors. This feedback generates knowledge that leads to necessary improvements for competition in the international arena.

We certainly use the feedback ... especially us who are not in the position to quantify any info we would like due to lack of available research findings ... feedback is something we use a lot as a means of improvement ...

A main theme from the interviews is how this knowledge may help to develop international product strategies. The question was whether to standardize the brand and its attributes across all markets or adapt it in several of them. And if adapted, what is the decisive feature of this 
adaptation. How is the brand going to be positioned in these markets? Interaction with and responses from tourists was a key factor leading to the exploitation of the national heritage of the brand.

In other words, the firms customized their brand positioning strategy for the tourism population and then extended this 'tourist' logic abroad. Therefore, now, there is a uniform, purely standardized image of the brands all over the world, which aims to communicate the message of 'Greekness' as a source of differentiation in foreign markets.

The following excerpt is characteristic of this

A basic element of $\mathrm{Z}$ brand is the word [ ... ] which reflects the whole concept of Greece. It is something we use everywhere, in communication, advertising, the brands themselves, packaging. It is a conscious choice of the firm that is not predicted to change. It is an element of the brand and has made all tourists visiting Greece to associate the brand with something Greek. And this is something we aim for, that $\mathrm{Z}$ is a Greek firm ... we have built all our brand and communication on that.

We can call such brands as Ethnobrands since they capitalize on the ethnic origin of the company and its accompanying properties and thus, promote culture-specific values communicated by the product. Such Ethnobrands are perceived by firms as powerful sources of differentiation whose market power was empirically tested through both the domestic, 'tourism-loaded' market and the international operations.

International tourism generated the knowledge on what foreign consumers value most, something which otherwise would demand extensive international market research, probably several failures through experimentation and huge costs associated with research and analysis of foreign cultures. Our case interviews clearly indicate that these firms were actively engaged with the tourist segments of their markets and saw promotional communications among tourists as a vehicle to help their internationalization:

Tourism is used as a means of promotion abroad since our orientation is entirely and clearly towards exporting... It is an opportunity for communicational approach of potential customers abroad.

An interesting insight yielded by the case studies is the utilization of domestic distribution as a means of international promotional strategy. Distribution within Greece was adapted to a more 'tourist' logic both in order to increase domestic sales and in order to serve the purpose of the exporting orientation of the firm. So, channels of distribution were integrated within the already existing network to work in favor of the promotion of the corporate and brands' image. Two of the firms created 
their own distribution outlet and became retailers themselves in order to exploit tourism as a powerful means of communication abroad. They opened two flagship stores in areas of high tourism mobility.

It is a spot near the city center's hotels and where the tourists go for their morning stroll, coffee or shopping. We had to do something like it, too ... as promotion, as image. An investment of tens of thousands of euros ... but you are obliged to do it. In order to show your unified image you need to take them to a good spot.

The companies made large investments to open these stores even though they expected them to be unprofitable; they did so to enhance their exporting orientation by having a high-quality promotional platform that would serve the global product policy of the firm (i.e. a retail channel that would reinforce the high-quality, Greek brand concept).

The reason was clearly communicational. We knew it beforehand that it would be a loss for us in terms of money. The target was to lose as less as possible and we believed that all this investment could be worth it through the communicational benefits we would have... Our target was to promote the brand and everything that this represents abroad; when you have the possibility to develop the brand the way you want in such a premium area and with such a large mobility of tourists, then it would be crazy to let it go.

The importance of such a strategic deviation in the trade policy of the firms in order to serve the internationalization goal is highlighted by the fact that such actions were implemented despite the fact that they damaged enormously long-established relations with their already existing network of retailers domestically.

You may not believe it, but we lost around 100 customers (retailers) when we opened the store at ...

Another distribution channel was the hotels sector and the amenity products they offer to their guests in the rooms. Firms create a whole range of product categories specifically aiming the hotel market in order to promote their image among tourists. The interesting point is that again this channel is not worthwhile in terms of profit margins and the only reason was to enhance their position within the tourists segment.

... the most important (issue) is communication ... we wanted to exploit the channel of hotels and respectively tourists in order to communicate the brand.

The third firm also adapted its distribution strategy within Greece in order to serve the purpose of additional sales and communication abroad. The intensification of distribution in tourist areas so as to increase the 
degree of contact tourists have with the product was deemed essential in order to increase brand awareness abroad and thus create an initial platform demand for further consumption in their home countries.

We try to have high distribution in tourists' areas so as to have an eponymous demand created but also to be able to respond to that by being at the place where tourists will ask for us.

\subsubsection{Internet-Based Communications with Tourists}

Last but not least, tourism was also the reason the firms standardized their Internet promotional strategy. After creating the initial connection with the consumer, this relationship had to be further enhanced when tourists went back home. And the best possible way to achieve that is through the Internet. This means of communication presented an excellent opportunity for the firm to retain the customers 'gained' in the tourism destination abroad.

There is a special category of emails; an amazing number of $70 \%$ of these emails was from tourists. Not from our regular consumer in e.g. Hong Kong but from a tourist who visited Greece and wanted to ask something.

With such an increasing number of tourists communicating with the firm, the firms had to take respective actions.

We decided to re-activate and upgrade the level of the site which was inactive until then, fill it with information in English only... there is no Greek site... and give information in which country we are, in which shop we are, by which ways the consumers can buy the product etc. ... serve the tourists who needed information but they couldn't find. So, we had a demand that wasn't in our plans and that's why we reactivated the site. To give the information needed and create a selling point we didn't have. We can now serve a Swiss tourist. But we don't have a selling point in Switzerland.

Tourism, therefore, altered the whole logic through which foreign markets are served and gave the impetus to internationalize firms' activities after having a platform demand created within Greece. Internet became the medium for this new form of internationalization of the firm.

They (tourists) made us sell through Internet ... to have in www.x.com a special place to sell because we lose sales at this point. Moreover, in Germany we don't have a selling point in Munich, only in Berlin and Frankfurt. And especially from Munich we had mails asking for foam baths, other from Paris, other from Italy etc. So, this is in our plans now because we lose sales. We said ... People who happened to come in contact with $\mathrm{X}$ while on holidays in Greece, what do we do with them afterwards?

Firm Y exploited the opportunities presented by the Internet even more by utilizing it as a bridge of communication and relationship development 
with prospective tourists before coming to Greece. They adapted their promotional strategy by utilizing online channels in order to integrate tourism with their exporting orientation in the best possible way. The phases through which a tourist passes pre (e.g. information search), during, and post trip were used as steps for the implementation of a holistic customer relationship management program which aims both to increase sales domestically and serve the purpose of internationalization.

The question is how we catch them here (pointing abroad - at tourists' home). Not when they are already here but before they are ... This must be combined with the exporting budget so even if he does not come you will make him consume there.

Therefore, there is a circular line of focused, adapted promotional actions taken by the firm which start at the country of residence of tourists and the market where the firm is active through exports, within Greece while tourists take their holidays and finally when tourists return home through Internet.

We get a lot of emails from foreign tourists who tell us congratulations, I drank your beverage, etc. We have communication with them, we send them gifts and we combine it with our exports ... we tell them where they can find the product so as to continue consuming it.

So, the trial level within Greece does not stop but is retained abroad in addition to the already existing customers who reinforce their relationship with the company even further when they return back home.

the volume (of emails) is huge ... either by people abroad who want to come to Greece for holidays and want to know where they will find the products ... or by people who have been to Greece, met the products here and ask where they can find them abroad.

Therefore, the Internet may serve as a tool for companies to overcome environmental uncertainty and may help improve strategic and operational performance for the Greek companies in pursuit of their international customers (Jean, Sinkovics, \& Kim, 2008; Yamin \& Sinkovics, 2007).

Summarizing, we saw that tourism worked along several lines. It created an initial platform of demand, it enhanced the corporate image, it made firms become knowledgeable of foreign needs and behaviors and altered the channels through which products are distributed by utilizing the Internet as the next step along the continuum between tourism destination and home country. It assisted to evaluate current business practices and improve them, assess levels of critical demand abroad, value the importance of knowledge for foreign operations, and tunnel the creativity of individuals towards innovative ways of thinking. 
Table 3. Tourism-Exports Linkage.

\begin{tabular}{|c|c|c|c|c|}
\hline \multicolumn{5}{|c|}{ Tourism-Exports Linkage } \\
\hline $\begin{array}{l}\text { Contribution of } \\
\text { tourism }\end{array}$ & $\begin{array}{l}\text { Knowledge } \\
\text { about foreign } \\
\text { consumers' } \\
\text { needs and } \\
\text { behaviors }\end{array}$ & $\begin{array}{r}\text { Creation of an ad } \\
\text { international co } \\
\text { domestically an } \\
\text { retention abroa }\end{array}$ & $\begin{array}{l}\text { ditional } \\
\text { nsumer base } \\
\text { d customer } \\
\text { d }\end{array}$ & $\begin{array}{l}\text { Enhancement of } \\
\text { International } \\
\text { Brand Equity }\end{array}$ \\
\hline $\begin{array}{l}\text { Respective actions } \\
\text { towards } \\
\text { international } \\
\text { operations }\end{array}$ & $\begin{array}{l}\text { Standardized } \\
\text { brand } \\
\text { positioning } \\
\text { and product } \\
\text { strategy - The } \\
\text { Ethnobrand }\end{array}$ & $\begin{array}{l}\text { Standardized } \\
\text { website utilized } \\
\text { as a tool for a } \\
\text { holistic } \\
\text { customer } \\
\text { relationship } \\
\text { management } \\
\text { program }\end{array}$ & $\begin{array}{l}\text { Customized } \\
\text { promotional } \\
\text { strategies } \\
\text { within } \\
\text { Greece }\end{array}$ & $\begin{array}{l}\text { Customized } \\
\text { tourism- } \\
\text { related } \\
\text { channels of } \\
\text { distribution } \\
\text { and promotion } \\
\text { within Greece }\end{array}$ \\
\hline
\end{tabular}

Table 3 summarizes the contribution of tourism towards the internationalization of firms and the respective actions that were implemented to exploit the tourism-exporting linkage.

\section{DISCUSSION AND PROPOSITIONS}

Existing research indicates that the dominant pattern of internationalization in Greece (the country context for the present study) is towards countries considered to be at a relatively low psychic distance from Greece, notably in the Balkans (Louri, Papanastassiou, \& Lantouris, 2000), rather than countries that most incoming tourists emanate from. Thus, while tourism can facilitate internationalization through enhanced knowledge of foreign consumer behavior and through brand enhancement, the majority of firms do not necessarily take advantage of these opportunities. This can be explained by the fact that market knowledge is clearly much broader than knowledge of consumers, and the presence of foreign tourists does not per se reduce (and certainly does not eliminate) other types of knowledge barriers with respect to foreign markets such as knowledge relating to institutional aspects, distribution systems and the business environment of foreign countries more generally (Evans \& Mavondo, 2002). Secondly, as our cases appear to indicate, knowledge of 'foreign' customer needs to be acquired, through the SMEs engaging with the tourist 
segments and is not necessarily generated automatically or through the mere presence of foreign tourists in the domestic market. Our case interviews indicate that firms treating incoming tourists as simply an additional 'bonus' and a source of 'effortless' additional revenue without incorporating tourism in their marketing strategy and practice are unlikely to gain sufficient insight into tourist behavior or gain knowledge beneficial to develop exports to the tourists' home countries. For these firms, an internationalization pattern based on low psychic distance may be perceived as being much less risky than that based on 'following' tourists to the home countries. We can thus put forward the following propositions with regard to the relationship between inbound tourism and firm internationalization:

Proposition 1. Inbound tourism can create firm knowledge relating to foreign consumer behavior that can help reduce barriers to developing exports to the home country of tourists.

Proposition 2. The more firms focus on tourist segments in their domestic marketing, the more likely it is that they will gain knowledge beneficial to developing exports to the tourists' home countries.

Our case studies also suggest that SMEs can leverage the 'locality' of their brands in their export development; in fact, in the context of our study, the development and use of 'Ethnobrands' is the concrete manifestation of firmspecific knowledge acquired by SMEs through their interactions with their tourist consumers. Thus:

Proposition 3. Inbound tourism provides an opportunity for local brand enhancement and internationalization.

An interesting and rather unexpected aspect of our findings is the firms reliance on Internet communication to build and maintain relationship with their tourist customers; this finding is particularly interesting, in the light of recent discussions of Internet-enabled 'disintermediation' and the effective bypassing of middlemen who are usually cited as a major obstacle for the success of internationalizing firms (Tiessen, Wright, \& Turner, 2001; Mahadevan, 2000). By a focused use of the Internet, SMEs can circumvent previously unavoidable channels of promotion and distribution in a foreign country, which made the internationalization process either extremely costly or not feasible due to the inadequacy to reach these channels. This is particularly relevant in the present context. As noted above, although, incoming tourism can reduce knowledge gap with respect to 
foreign consumer behavior, it does not reduce knowledge gaps with respect to the business and distribution system of foreign countries. However, our interviews indicate that by reliance on Internet-based communications with tourists, firms can positively leverage their internationalization (Yamin \& Sinkovics, 2006). Reflecting on our findings, it is perhaps not a coincidence that firms that developed their exporting activity in the home countries of tourists use the Internet extensively as a communication and transaction medium. However, the four firms that do not utilize tourism as a vehicle for internationalization do not emphasize the use of the Internet in any thing like the same degree. Thus, we put forward the following propositions:

Proposition 4. Tourism-based firm internationalization is likely to be hampered by lack of knowledge about the distribution system in the tourists' home countries.

Proposition 5. Reliance on e-commerce can benefit tourism-based internationalization by reducing dependence on the distribution system in the tourists' home countries.

\section{CONCLUDING REMARKS}

Empirical findings support the notion that internationalization processes are situation-specific and influenced by the context in which they originate, although it is also generally accepted that the pace of internationalization is increasing (Zafarullah, Ali, \& Young, 1998; Coviello \& McAuley, 1999). The present study is an exemplar of the 'peculiar' environment of a touristoriented economy that may generate significant opportunities for SMEs that otherwise face significantly more arduous barriers to internationalization; a tourism-oriented economy is clearly such a 'peculiar' context that deserves closer scrutiny. A particularly interesting insight generated from this study is how the combination of 'mobile' consumers and the development of the Internet as a medium for online internationalization (Yamin \& Sinkovics, 2006) may be reinforcing each other to positively impact opportunities for rapid internationalization by otherwise 'disadvantaged' SMEs. Another interesting finding is perhaps the identification of 'Ethnobrands' and their impact on SME internationalization. Despite the fact that local SMEs address to a multicultural audience, the Ethnobrand seems to have an edge over its global counterparts in specific product categories. The rise of such 
ethnic products in music, health treatments, garments, and food among others supports a prediction that Levitt's (1983) thesis regarding the supremacy of a global brand may be at stake.

Needless to say, this research is an exploratory one and does not aim to generalize findings to other contexts or product categories. The selection of cases was purposeful in order to highlight a not-cited phenomenon so, further research is needed which would include more firms in more product categories such as food which is a heavily culture-bound product category and would yield very interesting results. Additionally, Greece may be an archetypal tourism destination with a lot of internationalizing SMEs but it is a country which carries a strong and specific country-of-origin image among foreigners and this may affect their stance towards a Greek product. It is necessary to include firms originating in countries with diverse country and product images among visitors in order to test the effect of such a factor on the effectiveness of the effort to exploit the qualitative impact of tourism on consumer goods firms.

\section{NOTE}

1. It is also possible that firm may internationalize by 'following their customers abroad'. The manufacturer of 'Iron Brew' - a popular soft drink in Scotland apparently first developed its exports following Scottish holidaymakers to Mediterranean resorts - we are grateful to Stephen Young for this anecdote.

\section{REFERENCES}

Cheng, J. M. S., Blankson, C., Wu, P. C. S., \& Chen, S. S. M. (2005). A stage model of international brand development: The perspectives of manufacturers from two newly industrialized economies - South Korea and Taiwan. Industrial Marketing Management, $34,504-514$.

Coviello, N., \& McAuley, A. (1999). Internationalisation processes and the smaller firm: A review of contemporary empirical research. Management International Review, 39(3), 223-256.

Craig, C. S., \& Douglas, S. P. (2000). International marketing research (2nd ed.). Chichester, UK: Wiley.

Denis, J. E., \& Depelteau, D. (1985). Market knowledge, diversification and export expansion. Journal of International Business Studies, 16, 77-89.

Eriksson, K., \& Chetty, S. (2003). The effect of experience and absorptive capacity on foreign market knowledge. International Business Review, 12(6), 673-695. 
Evans, J., \& Mavondo, F. T. (2002). Psychic distance and organizational performance: An empirical examination of international retailing operations. Journal of International Business Studies, 33(3), 515-532.

Ghoshal, S. (1987). Global strategy: An organizing framework. Strategic Management Journal, $8(5), 425-440$.

Hadley, R. D., \& Wilson, H. I. M. (2003). The network model of internationalisation and experiential knowledge. International Business Review, 12(6), 697-717.

Inkpen, A. C. (1996). Creating knowledge through collaboration. California Management Review, 39(1), 123-140.

Jean, R. J. B., Sinkovics, R. R., \& Kim, D. (2008). Information technology and organizational performance within international business to business relationships - a review and an integrated conceptual framework. International Marketing Review, 25(5), $563-583$.

Johanson, J., \& Vahlne, J.-E. (1977). The internationalisation process of the firm - a model of knowledge development and increasing foreign commitments. Journal of International Business Studies, 8(1), 23-32.

Johanson, J., \& Vahlne, J.-E. (1990). The mechanism of internationalisation. International Marketing Review, 7(4), 11-24.

Johanson, J., \& Wiedersheim-Paul, F. (1975). The internationalisation of the firm-four Swedish cases. Journal of Management Studies, 12(3), 305-322.

Kogut, B., \& Zander, U. (1993). Knowledge of the firm and the evolutionary theory of the multinational corporation. Journal of International Business Studies, 24, 625-645.

Leonidou, L. C. (2004). An analysis of the barriers hindering small business export development. Journal of Small Business Management, 24(3), 279-302.

Levitt, T. (1983). The globalization of markets. Harvard Business Review (May-June), 92-102.

Liesch, P., \& Knight, G. (1999). Information internationalization and hurdle rates in small and medium enterprise internationalization. Journal of International Business Studies, 30(2), 383-394.

Louri, H., Papanastassiou, M., \& Lantouris, J. (2000). FDI in the EU periphery: A multinomial logit analysis of Greek firm strategies. Regional Studies, 34, 419-427.

Luostarinen, R. K. (1979). The internationalization of the firm. Helsinki: Acta Academic Oeconomicae Helsingiensis.

MacCannell, D. (1976). The tourist: A new theory of the leisure class. New York: Schocken.

Mahadevan, B. (2000). Business models for Internet based e-commerce: An anatomy. California Management Review, 42(4), 55-69.

Osland, G. E., \& Yaprak, A. (1995). Learning through strategic alliances: Processes and factors that enhance marketing effectiveness. European Journal of Marketing, 29(3), $52-66$.

Patton, M. Q. (1990). Qualitative evaluation and research methods. Newbury Park, CA: Sage.

Theodosiou, M., \& Leonidou, L. C. (2003). Standardization versus adaptation of international marketing strategy: An integrative assessment of the empirical research. International Business Review, 12(2), 141-171.

Tiessen, J. H., Wright, R. W., \& Turner, I. (2001). A model of e-commerce use by internationalizing SMEs. Journal of International Management, 7, 211-233.

Yamin, M., \& Sinkovics, R. (2006). Online internationalization, psychic distance reaction and the virtuality trap. International Business Review, 15(4), 339-360. 
Yamin, M., \& Sinkovics, R. (2007). ICT and MNE reorganization - the paradox of control. Critical Perspectives on International Business, 3(4), 322-336.

Yang, Y. S., Leone, R. P., \& Alden, D. L. (1992). A market expansion ability approach to identify potential exporters. Journal of Marketing, 56, 84-96.

Yu, L. (2003). The global brand advantage. Sloan Management Review (Spring), 13.

Zafarullah, M., Ali, M., \& Young, S. (1998). The internationalization of the small firm in developing countries - exploratory research from Pakistan. Journal of Global Marketing, 11(3), 21-38. 